УДК 329.1/.6-043.86(477)(1-32)

DOI: $10.24144 / 2218-5348.2019 .1-2(19-20) .83-110$

Шелемба Михайло,

кандидат політичних наук, дочент кафедри міжнародних студій та суспільних комунікацій

Шелемба Марта, кандидат політичних наук, викладач кафедри міжнародних студій та суспільних комунікацій ДВНЗ «Ужсгородський національний університет»

\title{
ТИПОВІ ТА ДЕВІАНТНІ РЕГІОНИ У КОНТЕКСТІ ЕВОЛЮЩЇ̈ УКРАЇНСЬКОЇ ПАРТІЙНОЇ СИСТЕМИ
}

У статті досліджується типовість / девіантність регіонів у контексті еволючії української партійної системи впродовж парламентських та місиевих електоральних ичиклів. Дослідження зазначеного показника здійснено за допомогою обчислення евклідової відстані, запропонованої Р. Туровським.

Окреслено існуючі типології регіонів залежно від типовості / девіантності, а також запропоновано визначення регіонально девіантних регіонів. Здійснено аналіз регіонів за вказаною ознакою на основі результатів парламентських виборів (1998 p., 2002 р., 2006 р., 2012 p., 2014 р.) та виборів до органів місиевого самоврядування (2010 p., 2015 р.).

Ключові слова: партійна система,політична партія, типові / девіантні регіони, евклідова відстань.

The study investigates typical / deviant regions in the context of the evolution of the Ukrainian party system supporting parliamentary and local electoral cycles. The study of this indicator was achieved to examine the Euclidean model.

It is indicated that the results of the 1998 parliamentary elections highlight the development of a party system that allows for opposition atypical regions. The distance at this time was an ideological struggle, and in the past has constantly dispersed in the vector "east-west". The description describes that for the results of the 2002 parliamentary elections, there is a transition from the ideological component of opposition in the electoral space to the component structure / opposition of the ruling political forces. A Euclidean survey of the 2006 election results, showing that what happens in the party system survey, using the factors used, using regional authorities in the area, and so on. According to the results of the 2012 parliamentary elections, the level of the national party system exists only 
once, when a formal functional system of the party system is used, the political party on a large scale is represented in different regions. Research on the results of the 2014 parliamentary elections has shown, having reconciled a significant split of electoral preferences in your vinyl class of small party systems. This tendency was in opposition to a certain growth of the national party system in Ukraine.

Keywords: party system, political party, typical / deviant regions, Euclidean distance.

Постановка проблеми. Процес рівномірності (однорідності) підтримки політичних партій у регіонах у період виборів на різних рівнях визначає ступінь націоналізації політичних акторіві загальнодержавну націоналізацію партійної системи. Тому націоналізація партійної системи країни залежить від типу поведінки регіонів під час тих чи інших виборів. У наукових джерелах зазначається:важливими ідентифікаторами такої поведінки $\epsilon$ типовість, яка обумовлює те, що регіони (населення) демонструють схожі тенденції в голосуванні, як і вся країна, або ж нетиповість (девіантність), що передбачає певні розколи у голосуванні порівняно із загальнодержавними трендами.

Аналіз останніх досліджень та публікацій. Питання типовості/девіантності регіонів досліджувались авторами на теоретичному (в працяхС. Мейнверінга і Т. Скаллі, Р. Хармела, Л. Свазенда,I. Григор'єва, Ф. Васселаї, Д. Карамані, Р. Туровського), емпіричному (в працях Д. Карамані, Д. Бошлера, В. Емануеле, Дж. Тієманна, Р.Туровського, Г. Голосова, І. Григор'єва, Ю. Якименка, Ю. Остапця) рівнях. Незважаючи на існування певних напрацювань у цій сфері дослідження, на сучасному етапі існує потреба визначення типовості/девіантності електоральної підтримки на регіональному та загальнонаціональному рівнях.

Мета статті - охарактеризувати типові/девіантні регіони в контексті розвитку партійної системи України. Для досягнення поставленої мети було визначено такі завдання:

1) вивчення теоретико-методологічних основ типовості / девіантності електоральної поведінки;

2) обчислення рівня евклідової відстані упродовж парламентських та місцевих електоральних циклів 1994-2015 рр.

3) визначення чинників, що впливають на рівень типовості та девіантності регіонів.

Результати дослідження.Аналіз поділу регіонів на типові й девіантні під час виборів у контексті фактичних результатів націоналізації партійної системи країни в наукових колах здійснюється переважноіз використанням параметричного показника евклідової відстані. Зміст такого показника грунтовно визначив Р. Туровський [4, с.172]. Вчений стверджує, що 
евклідова відстань демонструє відмінності в електоральній підтримці на рівні кожного з регіонів та країни загалом, політичні партії демонструють той або інший рівень націоналізації, а регіони - типовість чи нетиповість голосування за цих політичних акторів. На такому твердженні й побудований підхід, який на основі типологізації регіонів дає змогу доповнити вивчення націоналізації партійної системи. Досліджуваний показник визначається за відповідною формулою [4, с. 172].

Для методологічного обгрунтування аналітичної роботи важливо встановити критерії оцінки показника. Аналіз теоретично-методологічних та емпіричних матеріалів засвідчує, що за умов низького значення показника (менше 1) спостерігається типовість голосування в регіонах, і регіони зараховують до категорії типових [4, с.172]. За умов високого значення показника (понад 1) існує нетипове (девіантне) голосування, а регіони вважають нетиповими. Сформувалась певна наукова традиція класифікувати ці регіони за класами: опозиційні (регіон голосує проти провладних політичних партій), лояльні (конформістські) - спостерігається висока громадська активність на виборах, регіон залежить від влади, провладної партії, не демонструє опозиційного спротиву тощо; сепаратистські (регіони вважаються слабко інтегрованими в умови політичного простору країни, мають електоральні переваги стосовно підтримки вузькорегіональних політичних сил, можуть створювати сепаратистську загрозу для держави). У такій категорії пропонуємо використовувати також регіональну девіантність, що передбачає електоральну підтримку вузькорегіональних політичних сил, які не становлять загрози національній безпеці, але спрямовані на реалізацію інтересів певних регіональних політиків. На підставі зазначеного ми розробили класифікацію типів регіонів країни відповідно до характеру типовості / девіантості електоральної підтримки політичних партій під час виборчих процесів (табл. 1). У нашій класифікації визначено існуючі типології регіонів залежно від вказаної ознаки, а також запропоновано встановлення регіонально девіантних регіонів.

Практика дослідження евклідової відстані регіонів та їі зіставлення зі станом націоналізації набуває поширення у РФ. У розширення методології, та створення картини девіантних і типових регіонів країни вагомий внесок зробив Р. Туровський.

Ця проблематика висвітлена у статті Ю. Остапця та Р. МанайлоПриходько, які оцінили евклідову відстань регіонів за результатами парламентських виборів 1998-2014 рр. в Україні [1]. У рамках нашого дослідження зіставимо результати націоналізації партійної системи й евклідової відстані регіонів згідно з результатами парламентських і місцевих виборів за 1998-2015 pp. 


\section{Таблиця 1}

\section{Класифікація типів регіонів країни залежно від характеру типовості / девіантості електоральної підтримки політичних партій під час виборчих процесів}

\begin{tabular}{|c|c|c|}
\hline \multirow[t]{2}{*}{ За ставленням до влади } & \multicolumn{2}{|c|}{ Електоральні уподобання } \\
\hline & Типові & Девіантні \\
\hline Лояльні & $\begin{array}{lr}\text { Лояльно типові } & \text { (стандартна } \\
\text { лояльність } & \text { електоральної } \\
\text { підтримки } & \text { провладних } \\
\text { політичних сил) } & \end{array}$ & $\begin{array}{lr}\text { Лояльно } & \text { девіантні } \\
\text { (висока } & \text { електоральна } \\
\text { підтримка } & \text { провладних } \\
\text { політичних сил) }\end{array}$ \\
\hline Опозиційні & 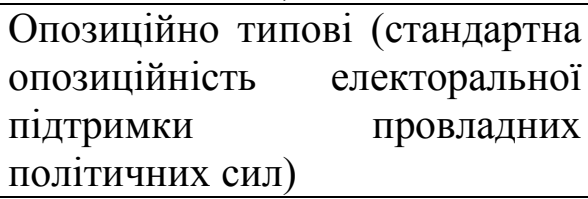 & $\begin{array}{l}\text { Опозиційно девіантні } \\
\text { (висока електоральна } \\
\text { підтримка опозиційних } \\
\text { політичних сил) }\end{array}$ \\
\hline Нейтральні & & $\begin{array}{l}\text { Регіонально девіантні } \\
\text { (висока електоральна } \\
\text { підтримка } \\
\text { вузькорегіональних } \\
\text { політичних сил, які не } \\
\text { становлять загрози } \\
\text { національній безпеці, } \\
\text { але спрямовані на } \\
\text { реалізацію інтересів } \\
\text { певних регіональних } \\
\text { політиків) }\end{array}$ \\
\hline
\end{tabular}

Типовість / девіантність регіонів за результатами парламентських виборів 1998 р. наведена у таблиці 2.

Як засвідчують дані, у 1998 р. в Україні було виокремлено: шість нетипових регіонів у розрізі електоральної участі у формуванні партійної системи.

Дніпропетровська область виявила високуопозиційну девіантність, підтримавши ВО «Громада» (так звана регіональна політична сила), яке очолював П. Лазаренко. Під час парламентських виборів 1998 р. партія позиціонувала себе як опозиційна до влади. Підтримка цієї партії в регіоні пов'язана 3 дією фактора центризму. Політики ВО «Громада», як і його очільник (П. Лазаренко), походили 3 Дніпропетровської області. Фактично цей регіон не може вважатись опозиційним. Електоральна підтримка пов’язана радше з впливом окремих політиків зазначеної політичної сили, частковим використанням ресурсів регіональної влади на рівні території. 


\section{Таблиия 2}

Типовість / девіантність регіонів за результатами парламентських виборів 1998 р.

\begin{tabular}{|c|c|c|}
\hline Регіон (область) & $\begin{array}{l}\text { Евклідова } \\
\text { відстань }\end{array}$ & Характер поведінки регіону \\
\hline 1 & 2 & 3 \\
\hline \multicolumn{3}{|l|}{ І. Типові } \\
\hline Вінницька & 0,56 & $\begin{array}{l}\text { Помірна електоральна підтримка провладного курсу, } \\
\text { лівої ідеології }\end{array}$ \\
\hline Волинська & 0,79 & $\begin{array}{l}\text { Підтримка правоцентристської ідеології, близька до } \\
\text { нетипової через високу підтримку правоцентристів }\end{array}$ \\
\hline Донецька & 0,74 & $\begin{array}{l}\text { Достатньо висока підтримка лівої ідеології, типова } \\
\text { для регіону, лояльність до провладного курсу. } \\
\text { Високе значення евклідової відстані (близьке до } \\
\text { нетипового) засвідчує про вплив фактору центризму } \\
\text { представників лівих політичних сил у регіоні, } \\
\text { лояльність до лівої ідеології та провладного курсу }\end{array}$ \\
\hline Житомирська & 0,37 & $\begin{array}{l}\text { Помірна підтримка лівої ідеології, спостерігається } \\
\text { підтримка правоцентристської ідеології }\end{array}$ \\
\hline Запорізька & 0,43 & $\begin{array}{l}\text { Достатньо висока підтримка лівої ідеології, типова } \\
\text { для регіону, простежується певна підтримка } \\
\text { правоцентристської ідеології }\end{array}$ \\
\hline Київська & 0,34 & $\begin{array}{l}\text { Переважає підтримка лівої ідеології, існує помірна } \\
\text { підтримка правоцентристської ідеології }\end{array}$ \\
\hline Кіровоградська & 0,42 & $\begin{array}{l}\text { Переважає підтримка лівої ідеології, спостерігається } \\
\text { помірна підтримка правоцентристської ідеології }\end{array}$ \\
\hline Луганська & 0,97 & $\begin{array}{l}\text { Велика підтримка лівої ідеології, типова для регіону. } \\
\text { Високе значення евклідової відстані засвідчує про } \\
\text { вплив фактора центризму представників лівих } \\
\text { політичних сил у регіоні. Значення, близьке до } \\
\text { нетипового через високу лояльність до лівої ідеології } \\
\text { та провладного курсу }\end{array}$ \\
\hline Миколаївська & 0,60 & $\begin{array}{l}\text { Висока підтримка лівої ідеології, типова для регіону, } \\
\text { існує помірна підтримка правоцентристської } \\
\text { iдеології }\end{array}$ \\
\hline Одеська & 0,37 & $\begin{array}{l}\text { Достатньо висока підтримка лівої ідеології, типова } \\
\text { для регіону; існує помірне підтримання } \\
\text { правоцентристської ідеології }\end{array}$ \\
\hline Полтавська & 0,52 & 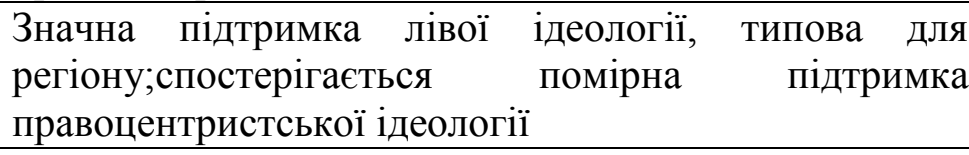 \\
\hline Сумська & 0,70 & $\begin{array}{l}\text { Значна підтримка лівої ідеології, } \\
\begin{array}{l}\text { регіону;простежується пова для } \\
\text { правоцентристської ідеології }\end{array} \\
\begin{array}{l}\text { помірна } \\
\text { підтримка }\end{array}\end{array}$ \\
\hline Харківська & 0,54 & $\begin{array}{l}\text { Переважає підтримка лівої ідеології, типова для } \\
\text { регіону }\end{array}$ \\
\hline Херсонська. & 0,43 & $\begin{array}{l}\text { Переважає підтримка лівої ідеології, типова для } \\
\text { регіону }\end{array}$ \\
\hline
\end{tabular}




\begin{tabular}{|c|c|c|}
\hline Хмельницька. & 0,51 & $\begin{array}{l}\text { Висока підтримка лівої ідеології, помірна підтримка } \\
\text { правоцентристської ідеології }\end{array}$ \\
\hline Черкаська & 0,60 & $\begin{array}{l}\text { Значна підтримка лівої ідеології; помірна підтримка } \\
\text { правоцентристської ідеології }\end{array}$ \\
\hline Чернівецька & 0,41 & $\begin{array}{llll}\text { Середній } & \text { рівень } & \text { електоральної } & \text { підтримки } \\
\text { провладного } & \text { курсу, } & \text { лівої ідеологіï, } & \text { помірна } \\
\text { підтримка правоцентристської ідеології } & \end{array}$ \\
\hline Чернігівська & 0,50 & $\begin{array}{l}\text { Велика підтримка лівої ідеології; помірна підтримка } \\
\text { правоцентристської ідеології }\end{array}$ \\
\hline м. Київ & 0,56 & $\begin{array}{lccr}\text { Середній } & \text { рівень } & \text { електоральної } & \text { підтримки } \\
\text { провладного } & \text { курсу, } & \text { лівої ідеології, } \\
\text { підтримка правоцентристської ідеології } & \end{array}$ \\
\hline АР Крим & 0,75 & $\begin{array}{l}\text { Переважає підтримка лівої ідеології, типова для } \\
\text { регіону. Значення близьке до нетипового через } \\
\text { високу лояльність до лівої ідеології та провладного } \\
\text { курсу }\end{array}$ \\
\hline м. Севастополь & 0,91 & $\begin{array}{l}\text { Переважає підтримка лівої ідеології, типова для } \\
\text { регіону. Значення близьке до нетипового внаслідок } \\
\text { високої лояльності до лівої ідеології та провладного } \\
\text { курсу }\end{array}$ \\
\hline II. Нетипові & & \\
\hline $\begin{array}{l}\text { Дніпропетровська } \\
\text { обл. }\end{array}$ & 1,18 & $\begin{array}{l}\text { Висока підтримка лівої ідеології, типова для регіону; } \\
\text { спостерігається } \\
\text { правоцентристської ідеології. Нетипове підтримання } \\
\text { регіональної партії - ВО «Громада», що одержала } \\
\text { найвищу підтримку в цьому регіоні. Опозиційна } \\
\text { девіантність }\end{array}$ \\
\hline Закарпатська & 1,24 & $\begin{array}{l}\text { Нетипова для регіону підтримка політичної партії, } \\
\text { що лобіює інтереси бізнесу, лояльна девіантність } \\
\text { регіону, яка проявляється у п підтримці } \\
\text { партіїпровладного курсу }\end{array}$ \\
\hline Івано-Франківська & 1,35 & $\begin{array}{l}\text { Опозиційна девіантність регіону, підтримка } \\
\text { провладного курсу }\end{array}$ \\
\hline Львівська & 1,27 & $\begin{array}{l}\text { Опозиційна девіантність регіону, підтримання } \\
\text { провладного курсу }\end{array}$ \\
\hline Рівненська & 1,02 & $\begin{array}{l}\text { Опозиційна девіантність регіону, підтримка } \\
\text { провладного курсу }\end{array}$ \\
\hline Тернопільська & 1,30 & $\begin{array}{l}\text { Опозиційна девіантність регіону, підтримання } \\
\text { провладного курсу }\end{array}$ \\
\hline $\begin{array}{l}\text { Націоналізація } \\
\text { партійної системи за } \\
1998 \text { р. }\end{array}$ & \multicolumn{2}{|c|}{ Пдм $=0,637$. Пгг =0,4* } \\
\hline
\end{tabular}

*Довідка: так Пдм - індекс націоналізації партійної системи за методологічним підходом М. Джонса і С. Мейнверінга; Пгг - індекс націоналізації партійної системи за методологічним підходом Г. Голосова.

Лояльну девіантність під час цих парламентських виборів виявила Закарпатська область, оскільки продемонструвала високу електоральну підтримку провладної політичної сили, що лобіює інтереси бізнесу. В цьому 
випадку, як засвідчують матеріали досліджень, можна акцентувати на ймовірності використання адміністративного ресурсу. Адже очільники політичної партії - В. Медведчук, Л. Кравчук, В. Онопенко-вагомо впливали на рівень різних органів управління, користуючись сталими зв'язками. Унаслідок високої підтримки в Закарпатській області політична сила отримала у 1998 р.місця в парламенті.

Чотири області Західного регіону (Івано-Франківська, Львівська, Рівненська, Тернопільська) опинились у складі нетипових електоральних регіонів через опозиційну девіантність. Вони продемонстрували опозиційність до провладного курсу. В цьому разі вирішальною була ідеологічна складова, і така ситуація,з нашого погляду, найхарактерніша для регіонів, аніж підтримка електоратом Закарпатської області провладної партї.

Типові регіони у 21 контексті електоральної участі в партієтворенні. Серед цих регіонів можна виокремити:регіони, що демонструють електоральну поведінку, близьку до нетипової: 1) Донецька, Луганська області, Автономна Республіка Крим, м. Севастополь, де спостерігається достатньо висока підтримка лівої ідеології, типова для регіону. Високе значення евклідової відстані засвідчує вплив фактора центризму представників лівих політичних сил у регіоні. Значення, близьке до нетипового, у цих регіонах пов'язане з високою лояльністю до лівої ідеології та провладного курсу; 2) Волинська область, яка характеризується підтримкою правоцентристської ідеології, близької до нетипової через високу підтримку правоцентристів (НРУ);

- регіони, що демонструють помірну електоральну поведінку провладного курсу, лівої ідеології (Вінницька область);

- регіони, котрі виявляють помірну підтримку лівої ідеології, правоцентристської ідеології (Житомирська область);

- регіони, яким притаманна підтримка лівої ідеології, певна підтримка правоцентристської ідеології (Запорізька, Київська, Кіровоградська, Миколаївська, Одеська, Полтавська, Сумська, Хмельницька, Черкаська, Чернівецька, Чернігівська області, м. Київ);

- регіони, що засвідчили підтримку лівої ідеології, типової для регіону (Харківська, Херсонська).

Процес структуризації партійної системи, продемонстрований середнім рівнем націоналізації (табл. 2), спричинив, на нашу думку, появу опозиційних нетипових регіонів.

Чотири області західного макрорегіону визначили фактичну підтримку правоцентристської політичної сили, що була ідеологічним суперником традиційних для 1998 р. лівих політичних сил. Відтак у цей 
період відбувалася ідеологічна боротьба, а в країні спостерігався розкол за вектором «схід-захід». Відбувалося формування національно орієнтованого електорату в рамках названих регіонів.

Електорат регіону Центральної України (Дніпропетровська область) формально вирізнявся опозиційною нетиповістю, але більшою мірою можна зауважити початок практики використання впливу на виборчий процес певних політиків у межах території.

Існував лояльний нетиповий регіон (Закарпатська область), що продемонстрував підтримку провладної партії антинаціонального спрямування. У регіоні під час виборів використовувались адміністративні ресурси, вплив окремих політиків, близьких до влади.

Типовість / девіантність регіонів за результатами парламентських виборів 2002 р. наведена в таблиці 3.

Таблицяя 3

\section{Типовість / девіантність регіонів за результатами парламентських виборів 2002 р.}

\begin{tabular}{|c|c|c|}
\hline Регіон (область) & $\begin{array}{c}\text { Евклідова } \\
\text { відстань }\end{array}$ & Характер поведінки регіону \\
\hline 1 & 2 & 3 \\
\hline \multicolumn{3}{|l|}{ 1. Типові } \\
\hline Вінницька & 0,75 & $\begin{array}{lrr}\text { Підтримка } & \text { проєвропейських } & \text { національно } \\
\text { орієнтованих політичних с сил, помірна електоральна } \\
\text { підтримка лівої ідеології }\end{array}$ \\
\hline Дніпропетровська. & 0,80 & $\begin{array}{l}\text { Висока підтримка лівої ідеології, типова для регіону, } \\
\text { середній рівень підтримки провладних політичних } \\
\text { сил }\end{array}$ \\
\hline Житомирська & 0,19 & $\begin{array}{llr}\text { Підтримка } & \text { проєвропейських } & \text { національно } \\
\text { орієнтованих політичних сил, помірна електоральна } \\
\text { підтримка лівої ідеології, незначна } \\
\text { провладних партій }\end{array}$ \\
\hline Закарпатська & 0,8 & $\begin{array}{l}\text { Підтримка проєвропейської національно орієнтованої } \\
\text { політичної сили, близька до нетипової, певна } \\
\text { підтримка політичної сили, близької до владного } \\
\text { курсу }\end{array}$ \\
\hline Запорізька & 0,84 & $\begin{array}{l}\text { Висока підтримка лівої ідеології, типова для регіону, } \\
\text { середній рівень підтримки провладних політичних сил }\end{array}$ \\
\hline Київська & 0,43 & $\begin{array}{l}\text { Переважає підтримка проєвропейських національно } \\
\text { орієнтованих політичних сил }\end{array}$ \\
\hline Кіровоградська & 0,60 & $\begin{array}{l}\text { Переважає підтримка лівої ідеології, помірна } \\
\text { підтримка провладної політичної сили та національно } \\
\text { орієнтованих політичних сил }\end{array}$ \\
\hline Миколаївська & 0,79 & $\begin{array}{l}\text { Домінує типова підтримка лівих політичних сил; } \\
\text { достатньо вагома підтримка провладних політичних сил }\end{array}$ \\
\hline
\end{tabular}




\begin{tabular}{|c|c|c|}
\hline Одеська & 0,70 & $\begin{array}{l}\text { Переважає типова підтримка лівих політичних сил; } \\
\text { починає формуватись орієнтир на підтримку } \\
\text { провладних політичних сил }\end{array}$ \\
\hline Полтавська & 0,89 & $\begin{array}{l}\text { Домінує підтримка лівої ідеології, спостерігається } \\
\text { помірна підтримка національно орієнтованих } \\
\text { політичних сил, невелика підтримка провладних } \\
\text { політичних сил }\end{array}$ \\
\hline Сумська & 0,45 & $\begin{array}{llc}\text { Переважає підтримка лівої ідеології; простежується } \\
\text { помірна підтримка національно орієнтованих } \\
\text { політичних сил та провладних політичних сил }\end{array}$ \\
\hline Харківська & 0,83 & $\begin{array}{l}\text { Має перевагу підтримка лівих політичних сил; } \\
\text { починає формуватись орієнтир на підтримку } \\
\text { провладних політичних сил }\end{array}$ \\
\hline Херсонська & 0,65 & $\begin{array}{l}\text { Переважає підтримка лівої ідеології, типова для } \\
\text { регіону, з'являється також орієнтир на підтримку } \\
\text { національно орієнтованих політичних сил та } \\
\text { провладних сил }\end{array}$ \\
\hline Хмельницька & 0,55 & $\begin{array}{l}\text { Переважає підтримка проєвропейських національно } \\
\text { орієнтованих політичних сил }\end{array}$ \\
\hline Черкаська & 0,6 & $\begin{array}{l}\text { Має перевагу підтримання } \\
\text { національно проєвропейських } \\
\text { спостерігається помірна електоральна підтримка лівої } \\
\text { ідеології, незначна підтримка провладних партій }\end{array}$ \\
\hline Чернівецька. & 0,99 & $\begin{array}{l}\text { Підтримка проєвропейської національно орієнтованої } \\
\text { політичної сили, близька до нетипової, певна } \\
\text { опозиційність до провладного курсу }\end{array}$ \\
\hline Чернігівська & 0,36 & $\begin{array}{l}\text { Рівномірно помірна підтримка проєвропейських } \\
\text { політичних сил та сил лівої ідеології; існує помірна } \\
\text { підтримка провладних партій }\end{array}$ \\
\hline м. Київ & 0,69 & 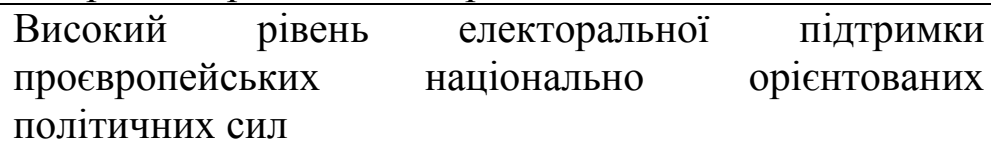 \\
\hline АР Крим & 0,87 & $\begin{array}{l}\text { Переважає підтримання лівої ідеології, типова для } \\
\text { регіону; з'являється також орієнтир на підтримку } \\
\text { національно орієнтованих політичних сил та } \\
\text { провладних сил }\end{array}$ \\
\hline \multicolumn{3}{|l|}{ 2. Нетипові } \\
\hline Донецька & 1.29 & $\begin{array}{l}\text { Лояльна девіантність, підтримка провладного руху, } \\
\text { лівих сил, які також лояльність до провладного курсу. } \\
\text { Переважає підтримка провладної партії через дію } \\
\text { фактора центризму (багато представників провладної } \\
\text { партії походили з Донбасу, мали там бізнес-інтереси, } \\
\text { керували промисловістю напряму й опосередковано), } \\
\text { ймовірність використання адміністративного ресурсу; } \\
\text { існувала підтримка лівої ідеології, яка поступилася } \\
\text { першій політичній силі за рівнем голосів }\end{array}$ \\
\hline Луганська. & 1.08 & $\begin{array}{l}\text { Лояльна девіантність, підтримка провладного руху, } \\
\text { лівих сил, які також лояльні до провладного курсу. } \\
\text { Переважає типова підтримка лівих політичних сил, }\end{array}$ \\
\hline
\end{tabular}




\begin{tabular}{|c|c|c|}
\hline & & $\begin{array}{l}\text { починає формуватись орієнтир на підтримку } \\
\text { провладних політичних сил }\end{array}$ \\
\hline Івано-Франківська & 2,31 & $\begin{array}{l}\text { Опозиційна девіантність регіону, підтримка } \\
\text { провладного курсу, підтримка проєвропейських } \\
\text { національно орієнтованих політичних сил }\end{array}$ \\
\hline Львівська & 1,72 & $\begin{array}{l}\text { Опозиційна девіантність регіону, підтримка } \\
\text { провладного курсу, підтримка проєвропейських } \\
\text { національно орієнтованих політичних сил }\end{array}$ \\
\hline Рівненська & 1,29 & $\begin{array}{l}\text { Опозиційна девіантність регіону, } \\
\text { провладного курсу та проєвропейських } \\
\text { ораціонально } \\
\text { орієнованих політичних сил }\end{array}$ \\
\hline Тернопільська & 1,93 & 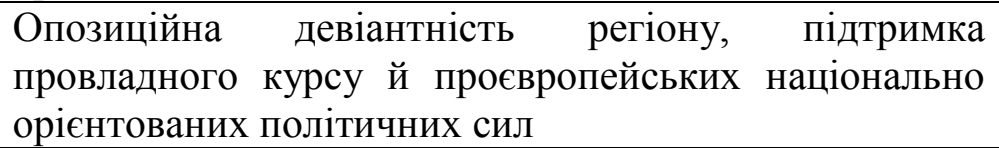 \\
\hline Волинська. & 1,42 & $\begin{array}{l}\text { Опозиційна девіантність регіону, підтримка } \\
\text { провладного курсу та проєвропейських національно } \\
\text { орієнтованих політичних сил }\end{array}$ \\
\hline м. Севастополь & 1,01 & $\begin{array}{l}\text { Лояльна девіантність, підтримка провладного руху, } \\
\text { лівих сил, які також лояльні до провладного курсу. } \\
\text { Переважає підтримка лівої ідеології, типова для } \\
\text { регіону, з’являється орієнтир на підтримання } \\
\text { провладних сил, незначна підтримка національно } \\
\text { орієнтованих політичних сил }\end{array}$ \\
\hline $\begin{array}{l}\text { Націоналізація } \\
\text { партійної системи } \\
\text { за } 2002 \text { р. }\end{array}$ & \multicolumn{2}{|c|}{ Пдм $=0,612$. Пгг $=0,493 *$} \\
\hline
\end{tabular}

*Довідка: так Пдм - індекс націоналізації партійної системи за методологічним підходом М. Джонса і С. Мейнверінга; Пгг - індекс націоналізації партійної системи за методологічним підходом Г. Голосова.

За результатами парламентських виборів 2002 р. було виокремлено:

Вісім нетипових регіонів у розрізі електоральної участі у формуванні партійної системи: Донецька, Луганська області та м. Севастополь виявили високу лояльну девіантність, підтримку провладного руху, лівих сил, які також лояльні до провладного курсу. Причому Донецька область, яка вважалась типовим регіоном, що підтримує ліву ідеологію, продемонструвала стрімке зростання прихильності до влади, провладних політичних сил. 3 огляду на фактор центризму (концентрація політиків провладних політичних сил в регіоні) й використання адміністративного ресурсу, було забезпечено високий рівень нетиповості підтримки (або іiі надвисокого рівня).

Нетиповим, з нашого погляду, видається те, що електорат Донецької області швидко зміг відмовитись від ідеологічних орієнтирів і почати активно підтримувати провладні політичні сили без певного ідеологічного фундаменту.

П’ять областей Західної України (Івано-Франківська, Львівська, Рівненська, Тернопільська, Волинська області) вирізняються опозиційною 
девіантністю електоральної поведінки, підтримкою провладного курсу, підтримкою проєвропейських, національно орієнтованих політичних сил (ВБ ПП «Блок Віктора Ющенка «Наша Україна», ВБ ПП «Виборчий блок Юлії Тимошенко»).

Як справедливо зазначають Ю. Остапець та Р. Манайло-Приходько, 3 2002 р. в Україні почали зникати ідеологічні протистояння в електоральному просторі. Їх замінила у випадку названих п’яти областей Західної України розбіжність або протистояння стосовно правлячої влади.

Існувало 19 типових регіонів у рамках електоральної участі в партієтворенні країни:

- Вінницька та Чернігівська області - $з$ підтримкою проєвропейських, національно орієнтованих політичних сил, помірною електоральною підтримкою лівої ідеології. Щодо цих двох регіонів спостерігаємо зміну електоральної прихильності, оскільки під час попередніх парламентських виборів їх виборці надавали більшу перевагу комуністам;

- Дніпропетровська, Запорізька, Миколаївська, Одеська, Харківська з підтримкою лівої ідеології, типової для регіонів, і провладних політичних сил. У цих регіонах починає формуватися орієнтир на підтримку провладних партій, практикується використання адміністративного ресурсу;

- Житомирська, Черкаська, Хмельницька області -3 переважною підтримкою проєвропейських, національно орієнтованих політичних сил, лівої ідеології, провладних політичних сил. Тут простежується зміна електоральної прихильності від підтримки лівих на попередніх парламентських виборах до переважання в голосуванні за національно орієнтовані опозиційні партії;

- Закарпатська область - із підтримкою проєвропейської національно орієнтованої політичної сили, близької до нетипової, певною підтримкою провладної політичної сили. Національно орієнтовані опозиційні сили тут змогли під час виборчої кампанії в 2002 р. здобути прихильність виборців регіону і змінити електоральний орієнтир попередніх виборів на провладний курс;

- Київська, Чернівецька області, м. Київ - з переважанням підтримки проєвропейських, національно орієнтованих політичних сил;

- Кіровоградська, Полтавська, Сумська, Херсонська області, Автономна Республіка Крим орієнтовані переважно на підтримку лівої ідеології, помірну підтримку провладної політичної сили та національно орієнтованих політичних сил.

Досліджуючи процес структуризації партійної системи, продемонстрований середнім рівнем націоналізації, який частково зріс за результатами парламентських виборів в Україні в 2002 р. порівняно з 1998 р., спостерігаємо існування: 
1. Опозиційних нетипових регіонів (як уже згадувалось, п’ять областей Західного регіону), орієнтованих на протистояння стосовно правлячої влади. У 2002 р. відбувся перехід від ідеологічної складової протистояння в електоральному просторі до складової підтримки / протистояння провладних політичних сил. У цьому випадку провладними були антиєвропейські політичні партії, проросійські, спрямовані на підтримання діючої влади, бізнес-інтересів певних груп або осіб.

2. Лояльних нетипових регіонів (Донецька, Луганська області, м. Севастополь), що демонструють підтримку провладного руху, лівих сил, які також лояльні до провладного курсу. Тут у процесі виборів для забезпечення високої підтримки використовувались адміністративні ресурси, вплив окремих політиків, близьких до влади.

Типовість / девіантність регіонів за результатами парламентських виборів 2006 р. наведена у таблиці 4.

Табличя 4

Типовість / девіантність регіонів за результатами парламентських виборів 2006 р.

\begin{tabular}{|c|c|c|}
\hline Регіон (область) & $\begin{array}{l}\text { Евклідова } \\
\text { відстань }\end{array}$ & Характер поведінки регіону \\
\hline \multicolumn{3}{|r|}{ 1. Типові } \\
\hline Дніпропетровська & 0,65 & $\begin{array}{l}\text { Переважає підтримка } \\
\text { регіоналізму, опозиція до діючої проєвропейської } \\
\text { національно орієнтованої влади, певна підтримка } \\
\text { демократичної, проєвропейської політичної сили } 3 \\
\text { огляду на фактор центризму (Ю. Тимошенко -лідер } \\
\text { Блоку Юлії Тимошенко проживає } \\
\text { Дніпропетровську) }\end{array}$ \\
\hline Житомирська & 0,59 & $\begin{array}{l}\text { Переважає підтримка провладного демократичного, } \\
\text { проєвропейського курсу }\end{array}$ \\
\hline Закарпатська & 0,69 & $\begin{array}{l}\text { Переважає підтримка провладного демократичного, } \\
\text { проєвропейського курсу }\end{array}$ \\
\hline Запорізька & 0,90 & $\begin{array}{l}\text { Переважає підтримка євроскептицизму, } \\
\text { регіоналізму, опозиція до діючої проєвропейської } \\
\text { національно орієнтованої влади }\end{array}$ \\
\hline Кіровоградська & 0,60 & $\begin{array}{l}\text { Переважає підтримка провладного демократичного, } \\
\text { проєвропейського курсу }\end{array}$ \\
\hline Миколаївська & 0,84 & $\begin{array}{l}\text { Переважає підтримка євроскептицизму, } \\
\text { регіоналізму, опозиція до діючої проєвропейської } \\
\text { національно орієнтованої влади }\end{array}$ \\
\hline Одеська & 0,79 & $\begin{array}{l}\text { Переважає підтримка } \\
\text { регіоналізму, опозиція до діючої проєкептицизму, } \\
\text { національно орієнтованої влади }\end{array}$ \\
\hline Полтавська & 0,54 & $\begin{array}{l}\text { Переважає підтримка провладного демократичного, } \\
\text { проєвропейського курсу }\end{array}$ \\
\hline
\end{tabular}




\begin{tabular}{|c|c|c|}
\hline Сумська. & 0,92 & $\begin{array}{l}\text { Переважає підтримка провладного демократичного, } \\
\text { проєвропейського курсу }\end{array}$ \\
\hline Харківська & 0,87 & $\begin{array}{l}\text { Переважає підтримка } \\
\text { регіоналізму, опозиція до діючої проєвропейської } \\
\text { національно орієнтованої влади }\end{array}$ \\
\hline Херсонська & 0,37 & $\begin{array}{l}\text { Переважає підтримка } 1 \text { євроскептицизму, } \\
\text { регіоналізму, опозиція до діючої проєвропейської } \\
\text { національно орієнтованої влади }\end{array}$ \\
\hline Хмельницька . & 0,98 & $\begin{array}{l}\text { Переважає підтримка провладного демократичного, } \\
\text { проєвропейського курсу }\end{array}$ \\
\hline Чернівецька. & 0,92 & $\begin{array}{l}\text { Переважає підтримка провладного демократичного, } \\
\text { проєвропейського курсу }\end{array}$ \\
\hline Чернігівська & 0,81 & $\begin{array}{l}\text { Переважає підтримка провладного демократичного, } \\
\text { проєвропейського курсу }\end{array}$ \\
\hline м. Київ & 0,99 & $\begin{array}{l}\text { Переважає підтримка провладного демократичного, } \\
\text { проєвропейського курсу }\end{array}$ \\
\hline \multicolumn{3}{|r|}{ 2. Нетипові } \\
\hline Донецька. & 1,87 & $\begin{array}{l}\text { Опозиційна девіантність регіону, підтримка } \\
\text { євроскептицизму, регіоналізму, опозиція до діючої } \\
\text { проєвропейської національно орієнтованої влади }\end{array}$ \\
\hline Луганська & 1,72 & $\begin{array}{l}\text { Опозиційна девіантність регіону, підтримка } \\
\text { євроскептицизму, регіоналізму, опозиція до діючої } \\
\text { проєвропейської національно орієнтованої влади }\end{array}$ \\
\hline Івано-Франківська & 1,65 & $\begin{array}{l}\text { Лояльна девіантність регіону, підтримка провладного } \\
\text { демократичного, проєвропейського курсу }\end{array}$ \\
\hline Львівська & 1,47 & $\begin{array}{l}\text { Лояльна девіантність } \quad \text { регіону, підтримка } \\
\text { провладного } \\
\text { курсу }\end{array}$ \\
\hline Рівненська. & 1,10 & $\begin{array}{l}\text { Лояльна девіантність регіону, підтримка } \\
\text { провладного } \\
\text { курсу }\end{array}$ \\
\hline Тернопільська & 1,46 & $\begin{array}{l}\text { Лояльна девіантність регіону, пiдтримка } \\
\text { провладного } \\
\text { курсу }\end{array}$ \\
\hline Волинська & 1,34 & $\begin{array}{l}\text { Лояльна } \\
\begin{array}{l}\text { певіантність } \\
\text { провладного } \\
\text { курсу }\end{array} \text { демократичного, проєвропейського }\end{array}$ \\
\hline Київська & 1,18 & $\begin{array}{l}\text { Лояльна девіантність регіону, підтримка } \\
\text { провладного } \\
\text { курсу }\end{array}$ \\
\hline Вінницька. & 1,05 & $\begin{array}{l}\text { Лояльна девіантність регіону, п підтримка } \\
\text { провладного } \\
\text { курсу }\end{array}$ \\
\hline Черкаська & 1,03 & $\begin{array}{l}\text { Лояльна девіантність регіону, підтримка } \\
\text { провладного } \\
\text { курсу }\end{array}$ \\
\hline АР Крим & 1,16 & $\begin{array}{l}\text { Опозиційна девіантність регіону, підтримка } \\
\text { євроскептицизму, регіоналізму, опозиція до діючої } \\
\text { проєвропейської національно орієнтованої влади }\end{array}$ \\
\hline
\end{tabular}




\begin{tabular}{|l|l|l|}
\hline м. Севастополь & 1,46 & $\begin{array}{l}\text { Опозиційна девіантність регіону, підтримка } \\
\text { євроскептицизму, регіоналізму, опозиція до діючої } \\
\text { проєвропейської національно орієнтованої влади }\end{array}$ \\
\hline $\begin{array}{l}\text { Націоналізація } \\
\begin{array}{l}\text { партійної системи за } \\
2006 \text { р. }\end{array}\end{array}$ & $\begin{array}{l}\text { Пдм }=0,641 . \text { Пгг }=0,5402 . \text { IPNrg }+ \text { IPNcnt }+ \text { IPNloc }=\text { IPNc }= \\
(1,025+0,06+1,409) / 3=0,831 .^{*}\end{array}$ \\
\hline
\end{tabular}

*Довідка: Пдм - індекс націоналізації партійної системи відповідно до методологічного підходу М. Джонса i С. Мейнверінга;Пгг - індекс націоналізації партійної системи згідно 3 методологічним підходом Г. Голосова;IPNc - індекс націоналізації партійної системи за авторським методологічним підходом; IPNrg націоналізація партій за результатами парламентських виборів у регіонах;IPNcnt - націоналізація партій за кандидатами від політичних партій у регіонах;IPNloc - націоналізація партій за результатами виборів до органів місцевого самоврядування

Аналіз стану типовості / девіантності регіонів за результатами парламентських виборів 2006 р. дав змогу дійти висновку, щов Україні електоральна поведінка регіонів за результатами парламентських виборів 2006 р. була структурованішою 3 огляду на покращення структуризації партійної системи. Серед нетипових регіонів можна виокремити: вісім областей, які засвідчують лояльну девіантність електоральної поведінки, підтримку провладного демократичного, проєвропейського курсу. Це 5 традиційних областей Західного регіону, Київська, Вінницька та Черкаська області. Зміна політичних орієнтирів виборців останніх трьох областей була забезпечена ефективною передвиборчою кампанією політичних сил вказаного напряму. Чотири регіони вирізнялись опозиційною девіантністю електоральної поведінки, підтримкою євроскептицизму, регіоналізму, опозицією до діючої проєвропейської національно орієнтованої влади. Попри типову електоральну поведінку цих територій, дуже високий рівень підтримки названої політичної сили засвідчує вплив фактора центризму, використання впливу регіональної влади на місцях та ін.

Дані таблиці 4 дають змогу з-поміж типових регіонів за результатами парламентських виборів 2006 р. виокремити такі: регіон, де переважає підтримка євроскептицизму, регіоналізму, існує опозиція до діючої проєвропейської національно орієнтованої влади, певна підтримка демократичної, проєвропейської політичної сили 3 огляду на фактор центризму (Дніпропетровська область); регіони, в яких переважає підтримка провладного демократичного, проєвропейського курсу (м. Київ, Житомирська, Закарпатська, Хмельницька, Чернівецька, Чернігівська, Кіровоградська, Полтавська, Сумськаобласті). У трьох останніх регіонах ситуація під час виборів дещо змінилась, оскільки раніше електорат здебільшого підтримував ліву ідеологію. На це великою мірою вплинули зміни часу, політичного режиму тощо;

- регіони, у котрих переважає підтримка євроскептицизму, регіоналізму, опозиція до діючої проєвропейської національно орієнтованої влади. Це - Запорізька, Миколаївська, Одеська, Харківська, Херсонська області. 
Такі електоральні уподобання загалом були типовими для цих регіонів у 2006 р. Структуризація партійної системи за результатами парламентських виборів вплинулана часткову зміну рівня націоналізації партійної системи України.

Типовість / девіантність регіонів за результатами місцевих виборів 2006 р. подана у таблиці 5.

Табличя 5

\section{Типовість / девіантність регіонів за результатами місцевих виборів 2006 р.}

\begin{tabular}{|c|c|c|}
\hline Регіон (область) & $\begin{array}{c}\text { Евклідова } \\
\text { відстань }\end{array}$ & Характер поведінки регіону \\
\hline 1 & 2 & 3 \\
\hline \multicolumn{3}{|r|}{ 1. Типові } \\
\hline Вінницька. & 0,62 & $\begin{array}{l}\text { Переважає підтримка провладного демократичного, } \\
\text { проєвропейського курсу; СП }\end{array}$ \\
\hline Дніпропетровська & 0,64 & $\begin{array}{l}\text { Переважає підтримка євроскептицизму, регіоналізму, } \\
\text { опозиція до діючої проєвропейської національно } \\
\text { орієнтованої влади, певна підтримка демократичної, } \\
\text { проєвропейської політичної сили з огляду на фактор } \\
\text { центризму (Ю. Тимошенко - лідер Блоку Юлії } \\
\text { Тимошенко - проживає у Дніпропетровську), } \\
\text { підтримка регіональної партії - Блок Лазаренка; СП }\end{array}$ \\
\hline Житомирська & 0,37 & $\begin{array}{l}\text { Переважає підтримка провладного демократичного, } \\
\text { проєвропейського курсу; СП }\end{array}$ \\
\hline Закарпатська & 0,49 & $\begin{array}{l}\text { Переважає підтримка провладного демократичного, } \\
\text { проєвропейського курсу; СП }\end{array}$ \\
\hline Запорізька & 0,76 & $\begin{array}{l}\text { Переважає підтримка євроскептицизму, регіоналізму, } \\
\text { опозиція до діючої проєвропейської національно } \\
\text { орієнтованої влади; СП }\end{array}$ \\
\hline Київська & 0,79 & $\begin{array}{l}\text { Переважає підтримка провладного демократичного, } \\
\text { проєвропейського курсу; СП (за меншого рівня } \\
\text { підтримки) }\end{array}$ \\
\hline Кіровоградська & 0,50 & $\begin{array}{l}\text { Переважає підтримка провладного демократичного, } \\
\text { проєвропейського курсу; СП }\end{array}$ \\
\hline Львівська & 0,64 & $\begin{array}{l}\text { Переважає підтримка провладного демократичного, } \\
\text { проєвропейського курсу; СП (за меншого рівня } \\
\text { підтримки) }\end{array}$ \\
\hline Миколаївська & 0,77 & $\begin{array}{l}\text { Переважає підтримка євроскептицизму, регіоналізму, } \\
\text { опозиція до діючої проєвропейської національно } \\
\text { орієнтованої влади; СП }\end{array}$ \\
\hline Одеська & 0,70 & $\begin{array}{l}\text { Переважає підтримка євроскептицизму, регіоналізму, } \\
\text { опозиція до діючої проєвропейської національно } \\
\text { орієнтованої влади; СП }\end{array}$ \\
\hline Полтавська & 0,30 & $\begin{array}{l}\text { Переважає підтримка провладного демократичного, } \\
\text { проєвропейського курсу; СП }\end{array}$ \\
\hline Рівненська & 0,76 & $\begin{array}{l}\text { Переважає підтримка провладного демократичного, } \\
\text { проєвропейського курсу; СП (за меншого рівня } \\
\text { підтримки) }\end{array}$ \\
\hline
\end{tabular}




\begin{tabular}{|c|c|c|}
\hline Сумська & 0,57 & $\begin{array}{l}\text { Переважає підтримка провладного демократичного, } \\
\text { проєвропейського курсу; СП }\end{array}$ \\
\hline Тернопільська & 0,92 & $\begin{array}{l}\text { Переважає підтримка провладного демократичного, } \\
\text { проєвропейського курсу; СП (за меншого рівня } \\
\text { підтримки) }\end{array}$ \\
\hline Харківська & 0,94 & $\begin{array}{l}\text { Переважає підтримка євроскептицизму, регіоналізму, } \\
\text { опозиція до діючої проєвропейської національно } \\
\text { орієнтованої влади; СП }\end{array}$ \\
\hline Херсонська & 0,38 & $\begin{array}{l}\text { Переважає підтримка євроскептицизму, регіоналізму, } \\
\text { опозиція до діючої проєвропейської національно } \\
\text { орієнтованої влади; СП }\end{array}$ \\
\hline Хмельницька & 0,64 & $\begin{array}{l}\text { Переважає підтримка провладного демократичного, } \\
\text { проєвропейського курсу; СП }\end{array}$ \\
\hline Черкаська & 0,62 & $\begin{array}{l}\text { Переважає підтримка провладного демократичного, } \\
\text { проєвропейського курсу; СП } \\
\text { підтримки) }\end{array}$ \\
\hline Чернівецька & 0,44 & $\begin{array}{l}\text { Переважає підтримка провладного демократичного, } \\
\text { проєвропейського курсу; СП (за меншого рівня } \\
\text { підтримки) }\end{array}$ \\
\hline Чернігівська & 0,45 & $\begin{array}{l}\text { Переважає підтримка провладного демократичного, } \\
\text { проєвропейського курсу; СП } \\
\text { підтримки) }\end{array}$ \\
\hline м. Київ & 0,74 & $\begin{array}{l}\text { Переважає підтримка провладного демократичного, } \\
\begin{array}{l}\text { проєвропейського курсу; СП } \\
\text { підтримки) }\end{array}\end{array}$ \\
\hline & & 2. Нетипові \\
\hline Донецька & 1,66 & $\begin{array}{l}\text { Опозиційна девіантність регіону, } \\
\text { євроскептицизму, регіоналізму, опозиція до діючкої } \\
\text { проєвропейської національно орієнтованої влади; СП }\end{array}$ \\
\hline Луганська & 2,05 & $\begin{array}{l}\text { Опозиційна девіантність регіону, підтримка } \\
\text { євроскептицизму, регіоналізму, опозиція до діючої } \\
\text { проєвропейської національно орієнтованої влади; СП }\end{array}$ \\
\hline Івано-Франківська & 1,09 & $\begin{array}{l}\text { Лояльна девіантність регіону, підтримка провладного } \\
\text { демократичного, проєвропейського курсу; СП }\end{array}$ \\
\hline Волинська & 1)$, & $\begin{array}{l}\text { Лояльна девіантність регіону, підтримка провладного } \\
\text { демократичного, проєвропейського курсу; СП }\end{array}$ \\
\hline АР Крим & 1,36 & $\begin{array}{l}\text { Опозиційна девіантність регіону, п підтримка } \\
\text { євроскептицизму, регіоналізму, опозиція до діючої } \\
\text { проєвропейської національно орієнтованої влади; } \\
\text { переважання підтримки регіональної партії (за } \\
\text { Януковича); СП }\end{array}$ \\
\hline м. Севастополь & 1,06 & $\begin{array}{l}\text { Опозиційна девіантність регіону, підтримка } \\
\text { євроскептицизму, регіоналізму, опозиція до діючої } \\
\text { проєвропейської національно орієнтованої влади; СП* }\end{array}$ \\
\hline $\begin{array}{l}\text { Націоналізація } \\
\text { партійної системи за } \\
\text { місцевими виборами } \\
2006 \text { р. }\end{array}$ & \multicolumn{2}{|c|}{ IPNloc $=1,409^{*}$} \\
\hline
\end{tabular}


Аналізуючи дані, доходимо висновку: - поділ регіонів України за ступенем типовості електоральної поведінки за парламентськими та місцевими виборами в Україні 2006 р. збігався, що великою мірою пов'язане 3 відповідністю у часі проведення двох виборчих кампаній; -за результатами двох виборів (парламентських та місцевих) 2006 р. найбільша девіантність електоральної поведінки спостерігалася у Донецькій та Луганській областях.

Типовість / девіантність регіонів за результатами парламентських виборів 2012 р. наведена у таблиці 6.

Таблиия 6

Типовість / девіантність регіонів за результатами парламентських виборів 2012 р.

\begin{tabular}{|c|c|c|}
\hline Регіон (область) & $\begin{array}{l}\text { Евклідова } \\
\text { відстань }\end{array}$ & Характер поведінки регіону \\
\hline 1 & 2 & 3 \\
\hline \multicolumn{3}{|r|}{ 1. Типові } \\
\hline Вінницька & 0,87 & $\begin{array}{l}\text { Переважає підтримка демократичного, } \\
\text { проєвропейського курсу, опозиційність до діючї } \\
\text { проросійської влади }\end{array}$ \\
\hline Волинська & 0,89 & $\begin{array}{l}\text { Переважає підтримка демократичного, } \\
\text { проєвропейського курсу, опозиційність до діючї } \\
\text { проросійської влади }\end{array}$ \\
\hline Дніпропетровська & 0,45 & 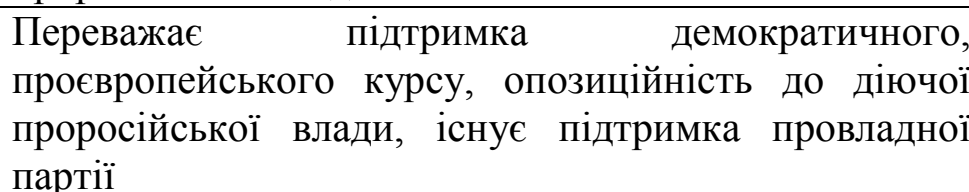 \\
\hline Житомирська & 0,51 & 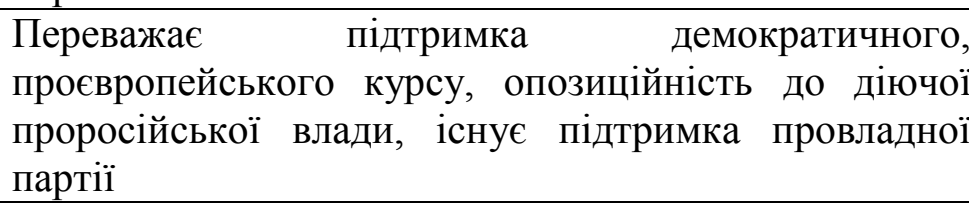 \\
\hline Закарпатська & 0,39 & $\begin{array}{l}\text { Переважає підтримка демократичного, } \\
\text { проєвропейського курсу, опозиційність до діючої } \\
\text { проросійської влади, існує підтримка провладної } \\
\text { партії }\end{array}$ \\
\hline Запорізька & 0,68 & $\begin{array}{l}\text { Переважає підтримка провладної проросійської } \\
\text { партії, що типово для регіону }\end{array}$ \\
\hline Київська & 0,61 & 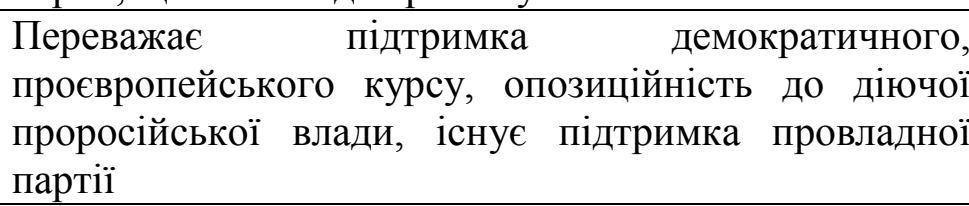 \\
\hline Кіровоградська & 0,32 & 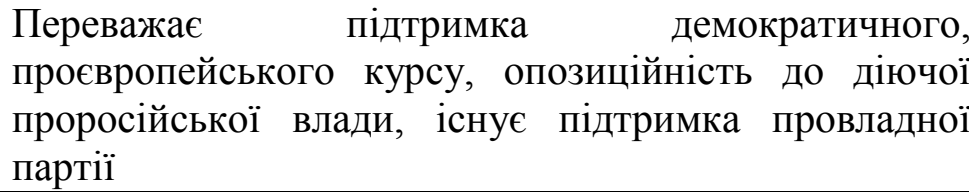 \\
\hline Миколаївська & 0,59 & $\begin{array}{lll}\text { Переважає } & \text { підтримка провладної } & \text { проросійської } \\
\text { партії, iснує підтримка } & \text { демократичних } \\
\text { проєвропейських сил } & & \end{array}$ \\
\hline
\end{tabular}




\begin{tabular}{|c|c|c|}
\hline Одеська & 0,66 & \begin{tabular}{lll} 
Переважає & \multicolumn{1}{c}{ підтримка провладної проросійської } \\
партії, iснує підтримка & демократичних \\
проєвропейських сил & & \\
\end{tabular} \\
\hline Полтавська & 0,89 & 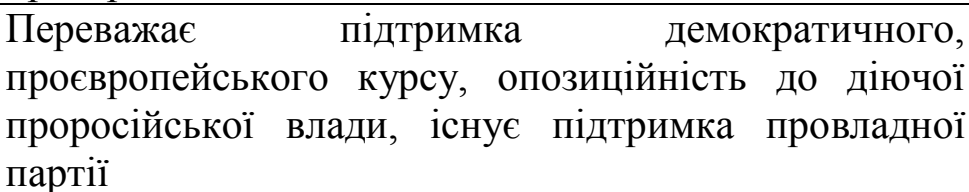 \\
\hline Рівненська & 0,76 & 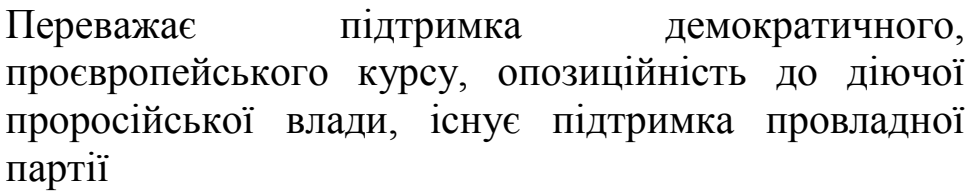 \\
\hline Сумська & 0,54 & 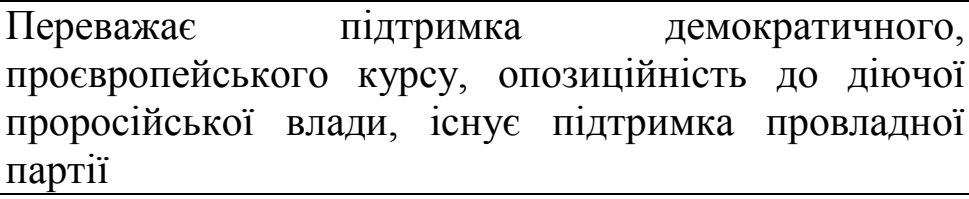 \\
\hline Харківська & 0,67 & \begin{tabular}{lll} 
Переважає & \multicolumn{1}{c}{ підтримка провладної } & проросійської \\
партії, iснує підтримка & демократичних \\
проєвропейських сил & & \\
\end{tabular} \\
\hline Херсонська & 0,45 & $\begin{array}{l}\text { Переважає підтримка демократичного, } \\
\text { проєвропейського курсу, опозиційність до діючої } \\
\text { проросійської влади, існує підтримка провладної } \\
\text { партії }\end{array}$ \\
\hline Хмельницька & 0,64 & 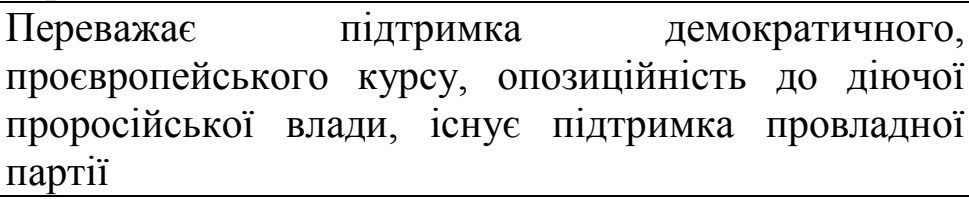 \\
\hline Черкаська & 0,64 & 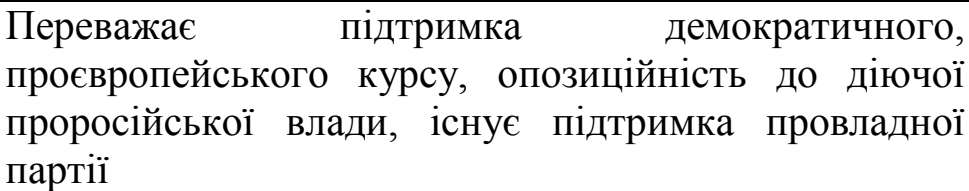 \\
\hline Чернівецька & 0,71 & 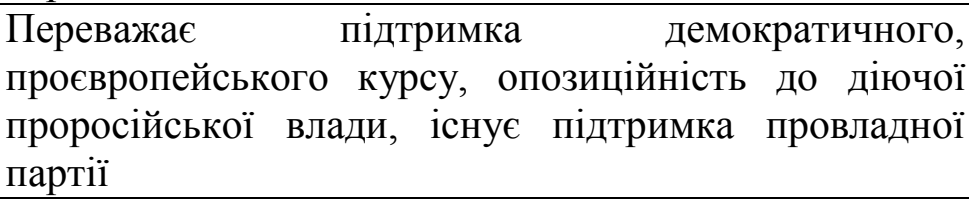 \\
\hline Чернігівська & 0,57 & 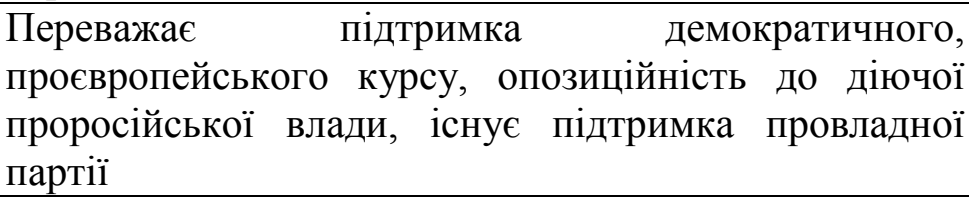 \\
\hline м. Київ & 0,96 & $\begin{array}{llr}\text { Переважає } & \text { підтримка } \\
\text { проєвропейського } & \text { курсу, опозиційність до діючичог̆ } \\
\text { проросійської влади, існує підтримка провладної партії }\end{array}$ \\
\hline & & 2. Нетипові \\
\hline Донецька & 1,59 & $\begin{array}{l}\text { Лояльна девіантність регіону, підтримка провладної } \\
\text { проросійської партії }\end{array}$ \\
\hline Луганська & 1,40 & $\begin{array}{l}\text { Лояльна девіантність регіону, підтримка провладної } \\
\text { проросійської партії }\end{array}$ \\
\hline Івано-Франківська & 1,41 & 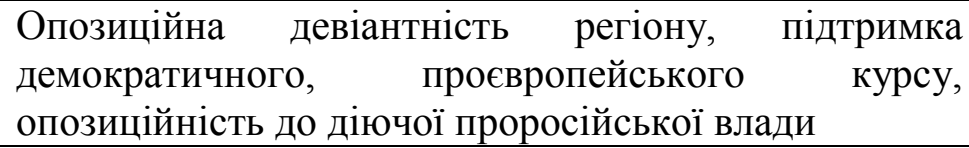 \\
\hline
\end{tabular}




\begin{tabular}{|c|c|c|}
\hline Львівська & 1,49 & $\begin{array}{l}\text { Опозиційна девіантність регіону, } \\
\text { демократичного, підтримка } \\
\text { опозиційність до діючої проросійської влади }\end{array}$ \\
\hline Тернопільська & 1,33 & $\begin{array}{lrrr}\text { Опозиційна девіантність } & \text { регіону, } & \text { підтримка } \\
\text { демократичного, } & \text { проєвропейського } \\
\text { опозиційність до діючої проросійської влади } & \end{array}$ \\
\hline АР Крим & 1,06 & $\begin{array}{l}\text { Лояльна девіантність регіону, підтримка провладної } \\
\text { проросійської партії, певна п्дтримка } \\
\text { демократичних сил }\end{array}$ \\
\hline м. Севастополь & 1,24 & $\begin{array}{l}\text { Лояльна девіантність регіону, підтримка провладної } \\
\text { проросійської партії }\end{array}$ \\
\hline $\begin{array}{l}\text { Націоналізація } \\
\text { партійної системи } \\
\text { за } 2012 \text { р. }\end{array}$ & \multicolumn{2}{|c|}{$\begin{array}{l}\text { Пдм }=0,691 . \text { Пгг }=0,6 . \mathrm{IPNrg}+\mathrm{IPNcnt}+\mathrm{IPNloc}=\mathrm{IPNc}=(0,7192+ \\
0,0685+1,001) / 3=0,596{ }^{*}\end{array}$} \\
\hline
\end{tabular}

* Довідка: Пдм - індекс націоналізації партійної системи згідно з методологічним підходом М. Джонса і С. Мейнверінга; Пгг - індекс націоналізації партійної системи відповідно до методологічного підходуГ. Голосова; IPNc- індекс націоналізації партійної системи за авторським методологічним підходом; IPNrg індекс націоналізації партій за результатами парламентських виборів урегіонах; IPNcnt - Iндекс націоналізації партій за кандидатами від політичних партій в регіонах; IPNloc - індекс націоналізації партій за результатами виборів до органів місцевого самоврядування

За даними розрахунків можемо констатувати, що результати парламентських виборів 2012 р. виявили існування:

1. Чотирьох регіонів, які характеризувались лояльною девіантністю електоральної поведінки, підтримкою провладної проросійської партії. Зазначимо також, що один 3 цих регіонів (Автономна Республіка Крим) вирізняється середнім рівнем підтримки демократичних сил (ПП ВО «Батьківщина»). Підтримка проросійських сил $є$ типовою для цих регіонів, але такий iї високий рівень пов’язаний 3 масштабним використанням адміністративного ресурсу в регіонах.

2. Трьох регіонів Західної України, які вирізнялись опозиційною девіантністю електоральної поведінки, підтримкою демократичного, проєвропейського курсу, опозиційністю до діючої проросійської влади. Це характерно для Західної України, але через масове використання адміністративного ресурсу скоротилась кількість регіонів, що в минулому вирізнялись масштабною підтримкою демократичних національних сил у державі.

3. Двох регіонів, які переважно підтримали демократичний, проєвропейський курс, виявивши опозиційність до діючої проросійської влади (Вінницька та Волинська області). Така електоральна орієнтація достатньо типова для цих регіонів, оскільки на попередніх парламентських та місцевих виборах 2006 р. вони засвідчили аналогічну підтримку демократичного курсу країни.

4. Регіонів 16, які продемонстрували переважну підтримку демократичного, проєвропейського курсу, опозиційність до діючої проросійської влади, певну підтримку провладної партії. Останнє великою 
мірою пов'язане з використанням адміністративного ресурсу, який був тоді акумульований у влади.

5. Регіону, де переважає підтримка провладної проросійської партії, що типово для регіону (Запорізька область). Порівняно 3 попередніми виборами електоральна поведінка регіону не змінилась.

6. Трьох регіонів (Миколаївська, Одеська, Харківська області), які засвідчили переважну підтримку провладної проросійської партії, певну підтримку демократичних, проєвропейських сил. Те, що в цих регіонах спостерігається середній рівень підтримки демократичних, проєвропейських сил, підтверджує певні зміни в електоральних перевагах населення, незважаючи на масштабне використання адміністративного ресурсу.

Як засвідчують дані, рівень націоналізації партійної системи показує невелике зростання, пов'язане з формальною стабілізацією партійної системи країни, курсом політичних партій на більш масштабне представлення у межах всіх регіонів.

Типовість / девіантність регіонів за результатами місцевих виборів 2010 р. подана у таблиці 7.Результати дослідження свідчать що під час місцевих виборів в Україні 2010 р. існували два регіони з лояльно девіантною електоральною поведінкою з підтримки проросійських партій. Це - Донецька та Луганська області. У процесі парламентських виборів їх поведінка була схожою. П'ять регіонів Західної України та м. Київ вирізнялись опозиційною девіантністю до проросійських політичних сил, але під час парламентських виборів радикальну опозиційність демонстрували лише три західних регіони.

Усі регіони, які вирізнялись типовою підтримкою демократичних сил, почали сприяти провладній проросійській партії з огляду на використання адміністративного ресурсу.

Таблиця 7

Типовість / девіантність регіонів за результатами місцевих виборів 2010 р.

\begin{tabular}{|c|c|c|}
\hline Регіон (область) & $\begin{array}{c}\text { Евклідова } \\
\text { відстань } \\
\end{array}$ & Характер поведінки регіону \\
\hline 1 & 2 & 3 \\
\hline \multicolumn{3}{|r|}{ 1. Типові } \\
\hline Вінницька & 0,95 & 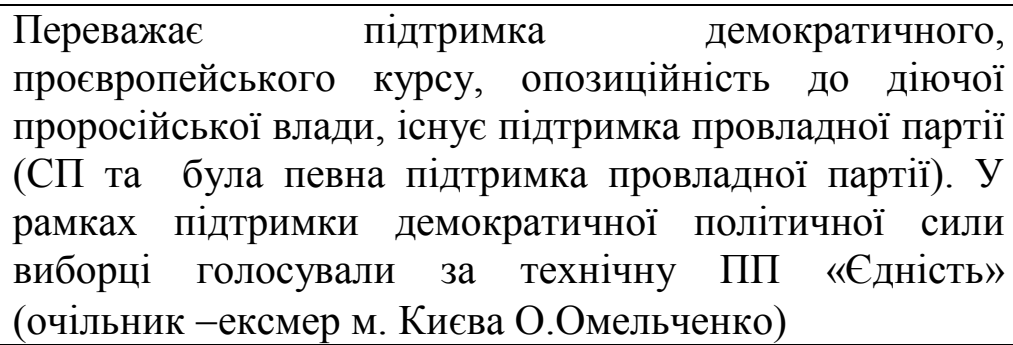 \\
\hline Волинська & 0,94 & $\begin{array}{l}\text { Переважає підтримка } \\
\text { проєвропейського демократичного, } \\
\text { проросійської влади, існує підтримка провладної партії } \\
\text { (СП та існувала певна підтримка провладної партії) }\end{array}$ \\
\hline
\end{tabular}




\begin{tabular}{|c|c|c|}
\hline Дніпропетровська & 0,67 & $\begin{array}{l}\text { Переважає підтримка проросійської партії, існує } \\
\text { підтримка демократичних проєвропейських сил (Пл) }\end{array}$ \\
\hline Житомирська & 0,63 & $\begin{array}{l}\text { Переважає підтримка проросійської партії, існує } \\
\text { підтримка демократичних проєвропейських сил (Пл) }\end{array}$ \\
\hline Запорізька & 0,79 & $\begin{array}{l}\text { Переважає підтримка провладної проросійської партії, } \\
\text { що типово для регіону (СП) }\end{array}$ \\
\hline Київська & 0,53 & $\begin{array}{l}\text { Переважає підтримка проросійської партії, існує } \\
\text { підтримка демократичних проєвропейських сил (Пл) }\end{array}$ \\
\hline Кіровоградська & 0,66 & $\begin{array}{l}\text { Переважає підтримка демократичного, проєвропейського } \\
\text { курсу, опозиційність до діючої проросійської влади, } \\
\text { iснує підтримка провладної партії (Сп) }\end{array}$ \\
\hline Миколаївська & 0,90 & $\begin{array}{l}\text { Переважає підтримка проросійської партії, iснує } \\
\text { підтримка демократичних проєвропейських сил (CП) }\end{array}$ \\
\hline Одеська & 0,67 & $\begin{array}{l}\text { Переважає підтримка проросійської партії, існує } \\
\text { підтримка демократичних проєвропейських сил (СпП }\end{array}$ \\
\hline Полтавська & 0,51 & $\begin{array}{l}\text { Переважає підтримка проросійської партії, існує } \\
\text { підтримка демократичних проєвропейських сил (Пл) }\end{array}$ \\
\hline Сумська. & 0,57 & $\begin{array}{l}\text { Переважає підтримка демократичного, проєвропейського } \\
\text { курсу, опозиційність до діючої проросійської влади, } \\
\text { iснує підтримка провладної партії (СП) }\end{array}$ \\
\hline Харківська & 0,58 & $\begin{array}{l}\text { Переважає підтримка проросійської партії, існує } \\
\text { підтримка демократичних проєвропейських сил (CП) }\end{array}$ \\
\hline Херсонська & 0,54 & $\begin{array}{l}\text { Переважає підтримка проросійської партії, існує } \\
\text { підтримка демократичних проєвропейських сил (Пл) }\end{array}$ \\
\hline Хмельницька & 0,63 & $\begin{array}{l}\text { Переважає підтримка демократичного, проєвропейського } \\
\text { курсу, опозиційність до діючої проросійської влади, } \\
\text { iснує підтримка провладної партії (CП) }\end{array}$ \\
\hline Черкаська & 0,54 & $\begin{array}{l}\text { Переважає підтримка проросійської партії, існує } \\
\text { підтримка демократичних проєвропейських сил (Пл*) }\end{array}$ \\
\hline Чернівецька & 0,74 & $\begin{array}{l}\text { Переважає підтримка демократичного, проєвропейського } \\
\text { курсу, опозиційність до діючої проросійської влади, } \\
\text { iснує підтримка провладної партії (CП) }\end{array}$ \\
\hline Чернігівська & 0,59 & $\begin{array}{l}\text { Переважає підтримка демократичного, проєвропейського } \\
\text { курсу, опозиційність до діючої проросійської влади, } \\
\text { iснує підтримка провладної партії (СП) }\end{array}$ \\
\hline АР Крим & 0,98 & $\begin{array}{l}\text { Переважає підтримка провладної проросійської партії, } \\
\text { що є типовим для регіону (СП } 3 \text { меншим рівнем } \\
\text { підтримки) }\end{array}$ \\
\hline м. Севастополь & 0,78 & $\begin{array}{l}\text { Переважає підтримка провладної проросійської партії, } \\
\text { що є типовим для регіону (СП з меншим рівнем } \\
\text { підтримки) }\end{array}$ \\
\hline & & 2. Нетипові \\
\hline Донецька & 1,7 & $\begin{array}{l}\text { Лояльна девіантність регіону, підтримка провладної } \\
\text { проросійської партії (СП) }\end{array}$ \\
\hline Луганська & 1,32 & $\begin{array}{l}\text { Лояльна девіантність регіону, підтримка провладної } \\
\text { проросійської партії (СП) }\end{array}$ \\
\hline $\begin{array}{l}\text { Івано- } \\
\text { Франківська }\end{array}$ & 1,41 & $\begin{array}{l}\text { Опозиційна девіантність регіону, } \\
\text { демократичного, підтримка } \\
\text { опозиційність до діючої проєвропейського }\end{array}$ \\
\hline
\end{tabular}




\begin{tabular}{|c|c|c|}
\hline Закарпатська & 1,39 & $\begin{array}{l}\text { Регіональна девіантність, підтримка вузькорегіональної } \\
\text { політичної сили (Єдиний центр), підтримка провладної } \\
\text { проросійської політичної сили (К*) }\end{array}$ \\
\hline Львівська & 1,92 & $\begin{array}{lrr}\text { Опозиційна девіантність } & \text { регіону, } & \text { підтримка } \\
\text { демократичного, } & \text { проєвропейського } & \text { курсу, } \\
\text { опозиційність до діючої проросійської влади }(\text { СП })\end{array}$ \\
\hline Рівненська & 1,07 & $\begin{array}{lrr}\text { Опозиційна девіантність } & \text { регіону, } & \text { підтримка } \\
\text { демократичного, } & \text { проєвропейського } & \text { курсу, } \\
\text { опозиційність до діючої проросійської влади }(\mathrm{CП})\end{array}$ \\
\hline Тернопільська & 1,84 & $\begin{array}{lrr}\text { Опозиційна девіантність } & \text { регіону, } & \text { підтримка } \\
\text { демократичного, } & \text { проєвропейського } & \text { курсу, } \\
\text { опозиційність до діючої проросійської влади }(\text { СП*) }\end{array}$ \\
\hline м. Київ & 1,89 & $\begin{array}{lrr}\text { Опозиційна девіантність } & \text { регіону, } & \text { підтримка } \\
\text { демократичного, } & \text { проєвропейського } & \text { курсу, } \\
\text { опозиційність до діючої проросійської влади }(\text { ВП*) }\end{array}$ \\
\hline $\begin{array}{l}\text { Націоналізація } \\
\text { партійної системи } \\
\text { за місцевими } \\
\text { виборами } 2010 \text { р. }\end{array}$ & \multicolumn{2}{|c|}{ IPNloc $=1,001^{*}$} \\
\hline
\end{tabular}

Зауважимо, що під час місцевих виборів Закарпатська область виявила регіональну девіантність, підтримавши вузькорегіональну політичну силу (Єдиний центр), яку очолював В. Балога. Ця політична сила надала підтримку провладній проросійській політичній силі.

Типовість / девіантність регіонів за результатами парламентських виборів 2014 р. подано у таблиці 8.

Таблицяя 8

Типовість / девіантність регіонів за результатами парламентських виборів 2014 р.

\begin{tabular}{|l|l|l|}
\hline Регіон (область) & $\begin{array}{l}\text { Евклідова } \\
\text { відстань }\end{array}$ & Характер поведінки регіону \\
\hline \multicolumn{2}{|c|}{$\mathbf{1 .}$ Типові } \\
\hline Вінницька & 0,71 & $\begin{array}{l}\text { Переважання підтримки демократичних, } \\
\text { проєвропейських політичних сил }\end{array}$ \\
\hline Волинська & 0,61 & $\begin{array}{l}\text { Переважання підтримки демократичних, } \\
\text { проєвропейських політичних сил }\end{array}$ \\
\hline Дніпропетровська & 0,73 & $\begin{array}{l}\text { Переважання підтримки демократичних, } \\
\text { проєвропейських політичних сил, середній рівень } \\
\text { підтримки проросійського курсу, євроскептицизм }\end{array}$ \\
\hline Житомирська & 0,34 & $\begin{array}{l}\text { Переважання підтримки демократичних, } \\
\text { проєвропейських політичних сил }\end{array}$ \\
\hline Закарпатська & 0,44 & $\begin{array}{l}\text { Переважання підтримки демократичних, } \\
\text { проєвропейських політичних сил }\end{array}$ \\
\hline
\end{tabular}




\begin{tabular}{|c|c|c|}
\hline Запорізька & 0,77 & $\begin{array}{l}\text { Переважання підтримки демократичних, } \\
\text { проєвропейських політичних сил, середній рівень } \\
\text { підтримки проросійського курсу, євроскептицизм }\end{array}$ \\
\hline Івано-Франківська & 0,78 & $\begin{array}{l}\text { Переважання підтримки демократичних, } \\
\text { проєвропейських політичних сил }\end{array}$ \\
\hline Київська & 0,40 & $\begin{array}{l}\text { Переважання підтримки демократичних, } \\
\text { проєвропейських політичних сил }\end{array}$ \\
\hline Кіровоградська & 0,26 & $\begin{array}{l}\text { Переважання підтримки демократичних, } \\
\text { проєвропейських політичних сил }\end{array}$ \\
\hline Львівська & 0,68 & $\begin{array}{l}\text { Переважання підтримки демократичних, } \\
\text { проєвропейських політичних сил }\end{array}$ \\
\hline Миколаївська & 0,51 & $\begin{array}{l}\text { Переважання підтримки демократичних, } \\
\text { проєвропейських політичних сил, середній рівень } \\
\text { підтримки проросійського курсу, євроскептицизм }\end{array}$ \\
\hline Одеська & 0,75 & $\begin{array}{l}\text { Переважання підтримки демократичних, } \\
\text { проєвропейських політичних сил, середній рівень } \\
\text { підтримки проросійського курсу, євроскептицизм }\end{array}$ \\
\hline Полтавська & 0,55 & $\begin{array}{l}\text { Переважання підтримки демократичних, } \\
\text { проєвропейських політичних сил }\end{array}$ \\
\hline Рівненська & 0,51 & $\begin{array}{l}\text { Переважання підтримки демократичних, } \\
\text { проєвропейських політичних сил }\end{array}$ \\
\hline Сумська & 0,29 & $\begin{array}{l}\text { Переважання підтримки демократичних, } \\
\text { проєвропейських політичних сил }\end{array}$ \\
\hline Тернопільська & 0,71 & $\begin{array}{l}\text { Переважання підтримки демократичних, } \\
\text { проєвропейських політичних сил }\end{array}$ \\
\hline Херсонська & 0,38 & $\begin{array}{l}\text { Переважання підтримки демократичних, } \\
\text { проєвропейських політичних сил }\end{array}$ \\
\hline Хмельницька & 0,39 & $\begin{array}{l}\text { Переважання підтримки демократичних, } \\
\text { проєвропейських політичних сил }\end{array}$ \\
\hline Черкаська & 0,35 & $\begin{array}{l}\text { Переважання підтримки демократичних, } \\
\text { проєвропейських політичних сил }\end{array}$ \\
\hline Чернівецька & 0,51 & $\begin{array}{l}\text { Переважання підтримки демократичних, } \\
\text { проєвропейських політичних сил }\end{array}$ \\
\hline Чернігівська & 0,48 & $\begin{array}{l}\text { Переважання підтримки демократичних, } \\
\text { проєвропейських політичних сил }\end{array}$ \\
\hline м.Київ & 0,55 & $\begin{array}{l}\text { Переважання підтримки демократичних, } \\
\text { проєвропейських політичних сил }\end{array}$ \\
\hline \multicolumn{3}{|r|}{ 2. Нетипові } \\
\hline Донецька & 1,43 & $\begin{array}{l}\text { Опозиційна девіантність регіону, підтримка } \\
\text { проросійського курсу, євроскептицизм, } \\
\text { опозиційність до діючої влади }\end{array}$ \\
\hline Луганська & 1,39 & $\begin{array}{l}\text { Опозиційна девіантність регіону, підтримка } \\
\text { проросійського курсу, євроскептицизм, } \\
\text { опозиційність до діючої влади }\end{array}$ \\
\hline Харківська & 1,13 & $\begin{array}{l}\text { Опозиційна девіантність регіону, підтримка } \\
\text { проросійського курсу, євроскептицизм, } \\
\text { опозиційність до діючої влади }\end{array}$ \\
\hline АР Крим & $\begin{array}{l}\text { Виборів } \\
\text { не було }\end{array}$ & \\
\hline
\end{tabular}




\begin{tabular}{|l|l|l|}
\hline м. Севастополь & $\begin{array}{l}\text { Виборів } \\
\text { не було }\end{array}$ & \\
\hline $\begin{array}{l}\text { Націоналізація } \\
\text { партійної системи за } \\
2014 \text { р. }\end{array}$ & \begin{tabular}{l} 
Пдм $=0,754$ Пгг $=0,63 ; \mathrm{IPNrg}+\mathrm{IPNent}+\mathrm{IPNloc}=\mathrm{IPNc}=(0,831+$ \\
\hline
\end{tabular} \\
\hline
\end{tabular}

* Довідка: Пдм - індекс націоналізації партійної системи відповідно до методологічного підходу М. Джонса i С. Мейнверінга; Пгг - індекс націоналізації партійної системи згідно з методологічним підходом Г. Голосова; IPNc- індекс націоналізації партійної системи за авторським методологічним підходом; IPNrg індекс націоналізації партій за результатами парламентських виборів в регіонах; IPNent - індекс націоналізації партій за кандидатами від політичних партій в регіонах; IPNloc -індекс націоналізації партій за результатами виборів до органів місцевого самоврядування.

Відтак можемо констатувати, що в Україні за результатами парламентських виборів 2014 р. було сформовано:

1. Три регіони з опозиційною девіантністю електоральної поведінки, підтримкою проросійського курсу, євроскептицизмом, опозиційністю до діючої влади. Це Донецька, Луганська та Харківська області, населення яких упродовж тривалого періоду перебувало під впливом проросійських політиків.

2. Чотири регіони 3 переважанням підтримки демократичних, проєвропейських сил, середнім рівнем підтримки проросійської політичної сили, опозиційної до діючої влади (Дніпропетровська, Запорізька, Миколаївська, Одеська області).

Загалом названі регіони, крім Запорізької області, й на попередніх парламентських виборах демонстрували схожу електоральну поведінку. Зменшення підтримки проросійської політичної сили здебільшого пов'язане зі скороченням можливостей використання адміністративних ресурсів;

3. Регіони 18, що демонструють переважання підтримки демократичних, проєвропейських політичних сил. Багато з них, зважаючи на усунення можливості використання адміністративного ресурсу на користь проросійських політичних сил, виявили таку підтримку в складний для України період. Це пов'язане 3 тим, що розкол країни за вектором «Схід-Захід» мав штучний характер.

Попри усунення вагомого розколу електоральних уподобань, у країні під час парламентських виборіву 2014 р. виникла система малих партій. Ця тенденція 3'явилась на противагу певному зростанню рівня націоналізації партійної системи в Україні.

Типовість / девіантність регіонів за результатами місцевих виборів 2015 р. подана у таблиці 9.

Таблиия 9

Типовість / девіантність регіонів за результатами місцевих виборів 2015 р.

\begin{tabular}{|l|l|l|}
\hline Регіон (область) & $\begin{array}{l}\text { Евклідова } \\
\text { відстань }\end{array}$ & Характер поведінки регіону \\
\hline \multicolumn{3}{|c|}{ 1. Типові } \\
\hline Вінницька & 0,44 & $\begin{array}{l}\text { Переважання підтримки демократичних, } \\
\text { проєвропейських політичних сил (СП) }\end{array}$ \\
\hline
\end{tabular}




\begin{tabular}{|c|c|c|}
\hline Волинська & 0,74 & 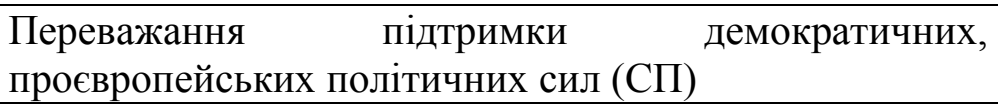 \\
\hline Житомирська & 0,38 & $\begin{array}{l}\text { Переважання } \begin{array}{c}\text { підтримки } \\
\text { проєвропейських політичних сил }(\mathrm{CП})\end{array} \\
\end{array}$ \\
\hline Запорізька & 0,98 & \begin{tabular}{lcc} 
Переважання & підтримки & \multicolumn{2}{c}{ демократичних, } \\
проєвропейських політичних сил, вагомий рівень \\
підтримки проросійського курсу, євроскептицизм (СП)
\end{tabular} \\
\hline Івано-Франківська & 0,61 & $\begin{array}{l}\text { Переважання } \begin{array}{c}\text { підтримки } \\
\text { проєвропейських політичних сил }(\mathrm{CП})\end{array} \\
\end{array}$ \\
\hline Київська & 0,37 & 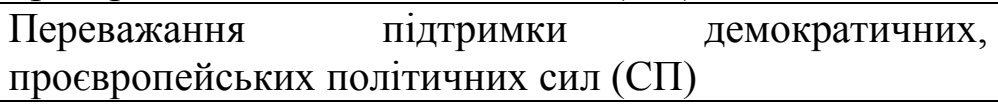 \\
\hline Кіровоградська & 0,47 & 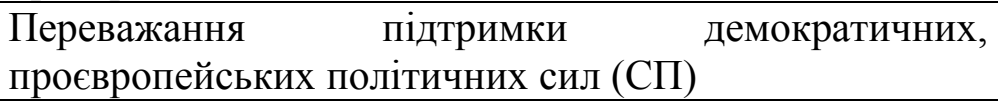 \\
\hline Львівська & 0,66 & $\begin{array}{l}\text { Переважання } \begin{array}{c}\text { підтримки } \\
\text { проєвропейських політичних сил }(\mathrm{CП})\end{array} \\
\end{array}$ \\
\hline Миколаївська & 0,81 & \begin{tabular}{lcc} 
Переважання & підтримки & \multicolumn{2}{c}{ демократичних, } \\
проєвропейських & політичних & сил, \\
підтримки пророй рівень
\end{tabular} \\
\hline Одеська & 0,86 & \begin{tabular}{lcc} 
Переважання & підтримки & \multicolumn{2}{c}{ демократичних, } \\
проєвропейських & політичних \\
підтримки проросійського курсу, євроскептицизм (СП)
\end{tabular} \\
\hline Полтавська & 0,56 & $\begin{array}{l}\text { Переважання } \begin{array}{c}\text { підтримки } \\
\text { проєвропейських політичних сил }(\mathrm{CП})\end{array} \\
\text { демократичних, }\end{array}$ \\
\hline Рівненська & 0,65 & 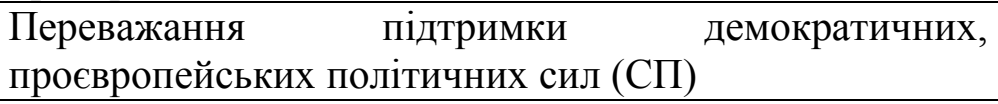 \\
\hline Сумська & 0,53 & $\begin{array}{l}\text { Переважання } \begin{array}{c}\text { підтримки } \\
\text { проєвропейських політичних сил }(\mathrm{CП})\end{array} \\
\end{array}$ \\
\hline Тернопільська & 0,64 & $\begin{array}{l}\text { Переважання } \begin{array}{c}\text { підтримки } \\
\text { проєвропейських політичних сил }(\mathrm{CП})\end{array} \\
\text { демократичних, }\end{array}$ \\
\hline Херсонська & 0,71 & 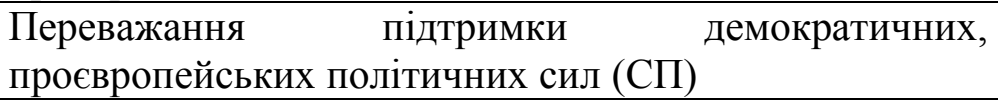 \\
\hline Хмельницька & 0,94 & 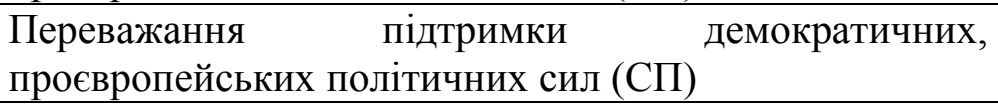 \\
\hline Черкаська & 0,75 & 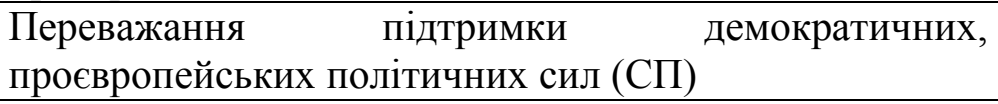 \\
\hline Чернівецька & 0,39 & 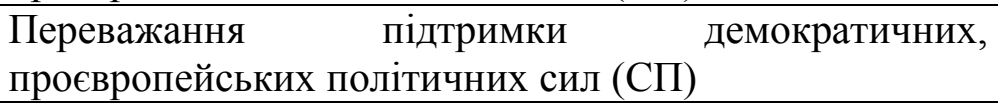 \\
\hline Чернігівська & 0,47 & 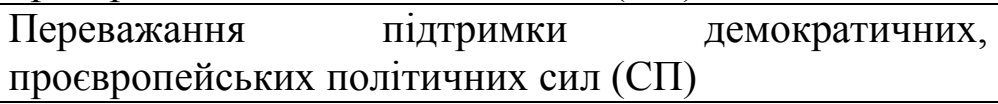 \\
\hline & & 2. Нетипові \\
\hline Донецька & $\begin{array}{l}\text { Виборів } \\
\text { не було }\end{array}$ & \\
\hline Луганська & $\begin{array}{l}\text { Виборів } \\
\text { не було }\end{array}$ & \\
\hline Дніпропетровська & 1,26 & $\begin{array}{l}\text { Опозиційна девіантність регіону, підтримка } \\
\text { проросійського курсу, євроскептицизм, опозиційність } \\
\text { до діючої влади (через вплив регіональних політиків); } \\
\text { середній рівень підтримки демократичних сил (Пл*) }\end{array}$ \\
\hline Закарпатська & 1,25 & $\begin{array}{lll}\text { Регіональна } & \text { девіантність, } & \text { підтримка }\end{array}$ \\
\hline
\end{tabular}




\begin{tabular}{|c|c|c|}
\hline & & $\begin{array}{l}\text { вузькорегіональної політичної сили (ПП «Сдиний } \\
\text { центр»), підтримка демократичних політичних сил } \\
\left(\mathrm{CП;} \mathrm{CM}^{*}\right)\end{array}$ \\
\hline м. Київ & 1,08 & $\begin{array}{lccc}\text { Лояльна } \quad \text { девіантність, } & \text { підтримка } & \text { провладної } \\
\text { політичної сили, демократичних сил }(\mathrm{C} п) & \end{array}$ \\
\hline Харківська & 1,46 & $\begin{array}{l}\text { Опозиційна девіантність регіону, підтримка } \\
\text { проросійського курсу, євроскептицизм, опозиційність } \\
\text { до діючої влади (через вплив регіональних політиків). } \\
\text { Підтримка Партії «Відродження», яка представлена } \\
\text { колишніми членами Партії регіонів (СП*) }\end{array}$ \\
\hline АР Крим & $\begin{array}{l}\text { Виборів } \\
\text { не було }\end{array}$ & \\
\hline м. Севастополь & $\begin{array}{l}\text { Виборів } \\
\text { не було }\end{array}$ & \\
\hline $\begin{array}{l}\text { Націоналізація } \\
\text { партійної системи } \\
\text { за місцевими } \\
\text { виборами } 2015 \text { р. }\end{array}$ & \multicolumn{2}{|c|}{ IPNloc $=1,018^{*}$} \\
\hline
\end{tabular}

*Довідка: IPNloc -Індекс націоналізації партій за результатами виборів до органів місцевого самоврядування; СП - орієнтир електоральної поведінки співпадає з парламентськими виборами; Пл - полярна відмінність 3 результатами парламентських виборів - переважна підтримка проросійської партії та існування підтримки демократичних сил; См - підтримка, схожа до підтримки на попередніх місцевих виборах

Аналіз даних засвідчує, що під час місцевих виборів електоральна поведінка більшості регіонів залишалась незмінною, окрім двох областей: 1. Закарпатської; вона, як і на попередніх місцевих виборах, демонструвала підтримку вузькорегіональної політичної сили (ПП «Єдиний центр»), хоча, як i під час парламентських виборів 2014 р., засвідчувала підтримку демократичних сил; 2. Дніпропетровської; вона відрізнялась опозиційною девіантністю, підтримкою проросійського курсу, євроскептицизмом, опозиційністю до діючої влади через вплив регіональних політиків, середнім рівнем підтримки демократичних сил. Під час парламентських виборів у 2014 р. регіон переважно орієнтувався на голосування за демократичні, національні політичні партії. Щодо голосування на місцевих виборах, за цим регіоном, як підтверджують матеріали аналітичних даних, спостерігалось багато виборчих маніпуляцій, траплялися випадки підкупу виборців різними політичними силами; ті ж самі заборонені технології забезпечення електоральної підтримки, що практикували за часів В. Януковича.

Висновки. Отже, ми дійшли висновків, що за результатами парламентських виборів 1998 р. спостерігається структуризація партійної системи, з'являються опозиційно нетипові регіони. Відтак у цей період відбувалася ідеологічна боротьба, а в країні спостерігався розкол за вектором «Схід-Захід». Результати парламентських виборів 2002 р. показали, що відбувається перехід від ідеологічної складової протистояння в електоральному просторі до складової підтримки / протистояння провладних політичних сил. Дослідження евклідової відстані за результатами виборів 2006 р. засвідчило, що 
відбувається збільшення структуризації партійної системи, спостерігається вплив фактора центризму, використання впливу регіональної влади на місцях та ін. Як засвідчують дані результатів парламентських виборів 2012 р., рівень націоналізації партійної системи показує невелике зростання, пов'язане 3 формальною стабілізацією партійної системи країни, курсом політичних партій на більш масштабне представлення у межах всіх регіонів. Дослідження результатів парламентських виборів 2014 р. підтвердило, що, попри усунення вагомого розколу електоральних уподобань, у країні виникла система малих партій. Ця тенденція з'явилась на противагу певному зростанню рівня націоналізації партійної системи в Україні.

\section{Список використаних джерел}

1. Остапець Ю., Манайло-Приходько Р. Типові чи девіантні: розрахунок евклідової відстані для аналізу особливостей регіонального голосування в Україні на парламентських виборах 1998-2014 pp. Розвиток політичної науки: європейські практики та національні перспективи: матеріали VIII міжнар. наук.-практ. конф. (Чернівці, 17 квіт. 2018 р.). Чернівці, 2018. С. 77-83.

2. Пархоменко С. Регіональні партії: чи $є$ загроза національній безпеці. Дата оновлення: 31.07.2018. URL: https:/petrimazepa.com/ hiddenthreat.html (дата звернення: 01.12.2019).

3. Ротар Н. Інституціональні чинники формування регіональних політичних режимів. Політичні процеси сучасності: глобальний та регіональний виміри: зб. матеріалів всеукр. науково-практ. конф. (м. ІваноФранківськ, 12-13 жовт. 2017 р.). Івано-Франківськ, 2017. С. 247-249.

4. Туровский Р. Национализация и регионализация партийных систем: подходы к исследованию. Полития: анализ, хроника, прогноз. 2016. № 1(80). С. 162-180.

5. Туровский Р. Электоральное пространство России: от навязчивой национализации к новой регионализации. Полития: анализ, хроника, прогноз. 2012. № 3(66). С. 100-120.

6. Угрин Л. Вплив регіональних ідентичностей на політичний процес в Україні. Регіональний вимір політичного процесу в Україні: матеріали міжрегіональної науково-практ. конф. Львів: ЦПД, 2007.С. 4-16.

7. Фесенко В. Партійна система України: чинники формування i трансформація. Україна - проблема ідентичності: людина, економіка, суспільство. Київ, 2003. С. 158-165. URL: https://petrimazepa.com/ hiddenthreat.html (дата звернення: 01.12.2019).

8. Шелемба М. Регіональні політичні партії в контексті дослідження процесу націоналізації (за результатами місцевих виборів 2015 р.). Грані. 2019. Вип. 1. С. 78-85. 


\section{REFERENSES}

1. Ostapec Yu., Manajlo-Prihodko R. Tipovi chi deviantni: rozrahunok evklidovoyi vidstani dlya analizu osoblivostej regionalnogo golosuvannya $\mathrm{V}$ Ukrayini na parlamentskih viborah 1998-2014. Rozvitok politichnoyi nauki: yevropejski praktiki ta nacionalni perspektivi: materiali VIII Mizhnar. nauk.-prakt. konf. (Chernivci, 17 kvit. 2018 r.). Chernivci, 2018. 77-83[in Ukrainian].

2. Parhomenko S. Regionalni partiyi: chi ye zagroza nacionalnij bezpeci. Data onovlennya: 31.07.2018.Retrieved from:https://petrimazepa.com/ hiddenthreat.html[in Ukrainian].

3. Rotar N. Institucionalni chinniki formuvannya regionalnih politichnih rezhimiv. Politichni procesi suchasnosti: globalnij ta regionalnij vimiri: zb. materialiv Vseukr. naukovo-prakt. konf. (Ivano-Frankivsk, 12-13 zhovt. 2017 r.). Ivano-Frankivsk, 2017, 247-249[in Ukrainian].

4. Turovskij R. Nacionalizaciya i regionalizaciya partijnyh sistem: podhody k issledovaniyu. Politiya: analiz, hronika, prognoz. 2016. № 1(80), 162180 [in Russian].

5. Turovskij R. Elektoralnoe prostranstvo Rossii: ot navyazchivoj nacionalizacii k novoj regionalizacii. Politiya: analiz, hronika, prognoz. 2012. № 3(66), 100-120[in Russian].

6. Ugrin L. Vpliv regionalnih identichnostej na politichnij proces $\mathrm{v}$ Ukrayini. Regionalnij vimir politichnogo procesu $\mathrm{V}$ Ukrayini: materiali mizhregionalnoyi naukovo-prakt. konf. Lviv: CPD, 2007, 4-16[in Ukrainian].

7. Fesenko V. Partijna sistema Ukrayini: chinniki formuvannya i transformaciya. Ukrayina - problema identichnosti: lyudina, ekonomika, suspilstvo. Kiyiv, 2003, 158-165. Retrieved from: https://petrimazepa.com/ hiddenthreat.html [in Ukrainian].

8. Shelemba M. Regionalni politichni partiyi v konteksti doslidzhennya procesu nacionalizaciyi (za rezultatami miscevih viboriv 2015 r.). Grani. 2019. Vip. 1, 78-85[in Ukrainian]. 